ORIGINAL ARTICLE

\title{
Repellent Activity of $N$-Hexane Extract from Ocimum Basilicum Leaves and Stem Against Aedes Aegypti
}

\author{
Indri Ramayanti ${ }^{1}$, Ratika Febriani ${ }^{1}$, Annisa Nurul Jannah ${ }^{2}$ \\ ${ }^{1}$ Department of Parasitology, Faculty of Medicine, University of Muhammadiyah Palembang \\ ${ }^{2}$ Faculty of Medicine, University of Muhammadiyah Palembang \\ Correspondence email: indri.fkumpalembang@gmail.com
}

\begin{abstract}
Aedes aegypti is known to be a major vector for dengue hemorrhagic fever. Vector control involves repellent usage. Synthetic repellent is known to be corrosive and natural repellent might be safer and more environmentally friendly. Ocimum basilicum stem and leaves contain essential oil with bioactivity against Aedes aegypti. This research aims to analyze the bioactivity of repellent from Ocimum basilicum $n$-hexane extract and demonstrate the effective concentration (EC90) against Aedes aegypti. Designed of this research was random complete experimental. The repellent activity was tested according to the repellent test guideline and Standardized Household Pesticide Efficacy Test Protocol. The extract was diluted into $15 \%, 25 \%$, and $35 \%$ using $96 \%$ ethanol and applied to a black cloth that was fixed against the wall of a test cage. Negative control using $96 \%$ ethanol and positive control was achieved with $13 \%$ DEET (brand X repellent). The repellent activity was analyzed using a one-way ANOVA and Probit test. The results of the average percentage repellency on leaf extracts and basil stems with concentrations of $15 \%, 25 \%$, and $35 \%$ were $75 \%, 85.05 \%$, and $92.51 \%$, respectively. EC90 was achieved at $45.13 \%$. $N$-hexane extracts from basil stem and leaves therefore proven as effective against Aedes aegypti.
\end{abstract}

Keywords: Aedes aegypti, Ocimum basilicum stem, and leaves, repellent

\section{INTRODUCTION}

Dengue hemorrhagic fever (DHF) is caused by Dengue virus (an arthropodborne virus), genus Flavivirus, Flaviviridae family. DHF is transmitted by mosquito bites from Aedes genus; usually by Aedes aegypti or Aedes albopictus. DHF can be found year long and all ages group. ${ }^{1}$ DHF in Indonesia is mainly found in dense areas, such as Java, Bali, and Sumatra. $^{2}$ DHF incidence in South Sumatra was increasing from 2013 to 2014. ${ }^{3}$

Because of DHF impact in society, preventive actions, such as mosquito nests eradication, water storage cleaning (including water drums, reservoir tanks, buckets, etc.), covering water storage, and burying trashes, are increasingly important. ${ }^{2}$ Mosquito repellent is used for personal protective measure against mosquito bites. ${ }^{4}$

Repellent is a family of household pesticides. Repellent is mainly provided in lotion and spray forms. Repellent contains diethyl-meta toluamide (DEET), a highly dangerous and corrosive substance. Chronic high-intensity usage may result in insomnia, muscle cramps, mood 
disturbances, skin rashes, upper respiratory tract irritation. $^{5}$

Domestic plants, such as basil (Ocimum basilicum), may prove as an alternative for repellent against Aedes aegypti. Ocimum basilicum contains bioactive compounds in the form of alkaloids, tannins, lignin, saponins, flavonoids, triterpenoids, steroids, and essential oils. ${ }^{6,7}$ Essential oil from basil leaves and stem contain methyl chavicol, linalool, geraniol, eugenol, caryophyllene, neral, etc. Linalool and geraniol are phenolic compounds with mosquito repellent activity. ${ }^{8}$

Nonpolar solvents, such as petroleum ether or $n$-hexane, are required to extract nonpolar components from plant tissues; meanwhile, more polar compounds require more polar solvents, such as ethanol or methanol. ${ }^{9}$ Solvent used in extraction makes an impact in the composition of essential oils extracted from the plant. For example, the best extraction solvent for lemongrass (Cymbopogon winterianus) is $n$-hexane (compared to ethanol or acetone). ${ }^{7}$

Therefore, repellents against Aedes aegypti from natural resources, such as $n$ hexane extracts of Ocimum basilicum stem and leaves, are a highly promising field of research.

\section{METHODS}

This research was designed as an experimental complete random research. The research was conducted in the Laboratory of Parasitology, Medical Faculty of Muhammadiyah University, Palembang. This research was conducted in October-November 2019.

\section{Extraction}

One kilogram of fresh Ocimum basilicum stem and leaves were washed and the leaves were separated. Leaves and stems of Ocimum basilicum were dried.
Dried Ocimum basilicum stem and leaves were macerated using a blender and the resultant powder was weighed (amounted 500 grams).

The active compound from Ocimum basilicum powder was extracted using the $n$-hexane solvent. Ocimum basilicum powder was put in a maceration jar, 2 liters of $n$-hexane solvent were added, mixed, and left for 24 hours. The process was repeated for 3 times. The resultant mix was evaporated.

The evaporated extract was diluted for $15 \%, 25 \%$, and $35 \%$ concentration using $96 \%$ ethanol. The viscous extract was diluted by adding $96 \%$ ethanol to obtain a concentration of $15 \%, 25 \%$, and $35 \%$. The negative control was ethanol $(96 \%)$, while the positive control was repellant $\mathrm{X}$ containing DEET 13\%. All sprays were put in a 25 spray bottle.

\section{Repellent activity test}

This research utilized adult female Aedes aegypti from the sterile colony. The Aedes aegypti was provided by Laboratorium Entomology, Lokalitbang P2B2, Baturaja, South Sumatra. Aedes aegypti was nurtured from larval stage I through IV until the adult stage (around 5 days) and fed with pellets. Larvae that have been transformed into pupae were moved into $500 \mathrm{~mL}$ glass containing water for maturation (around 1-2 days). During the developmental stage, adult mosquitoes were fed sugary water until 12-24 hours before the test. Before the test, male and female mosquitoes were separated. Female Aedes aegypti were placed inside the nurturing cage.

The repellent activity was tested using repellent test guidelines and Standardized Household Pesticide Efficacy Test Protocol with black clothes on the wall of a test cage. The positive control, negative control, and $n$-hexane extracts were sprayed on the clothes. Twenty-five 
Aedes aegypti were put inside each test cage and the number of mosquitoes in the clothes was observed on each hour for 5 minutes. The observation was conducted for an hour 0 (immediately after application) to hour six. The tests were repeated 3 times using different clothes and mosquitoes. ${ }^{10,11}$

Protection capability of repellent was analyzed statistically using one-way ANOVA and $90 \%$ of effectiveness concentration (EC90) were analyzed using
Probit analysis $\quad(95 \%$ confidence interval). ${ }^{12}$

\section{RESULTS}

Repellent activity test of $n$-hexane extract of Ocimum basilicum stem and leaves was conducted for 6 hours. The result shown on the graph below, showing the percentage of the effective concentration of $n$-hexane extract of Ocimum basilicum stem and leaves against Aedes aegypti.

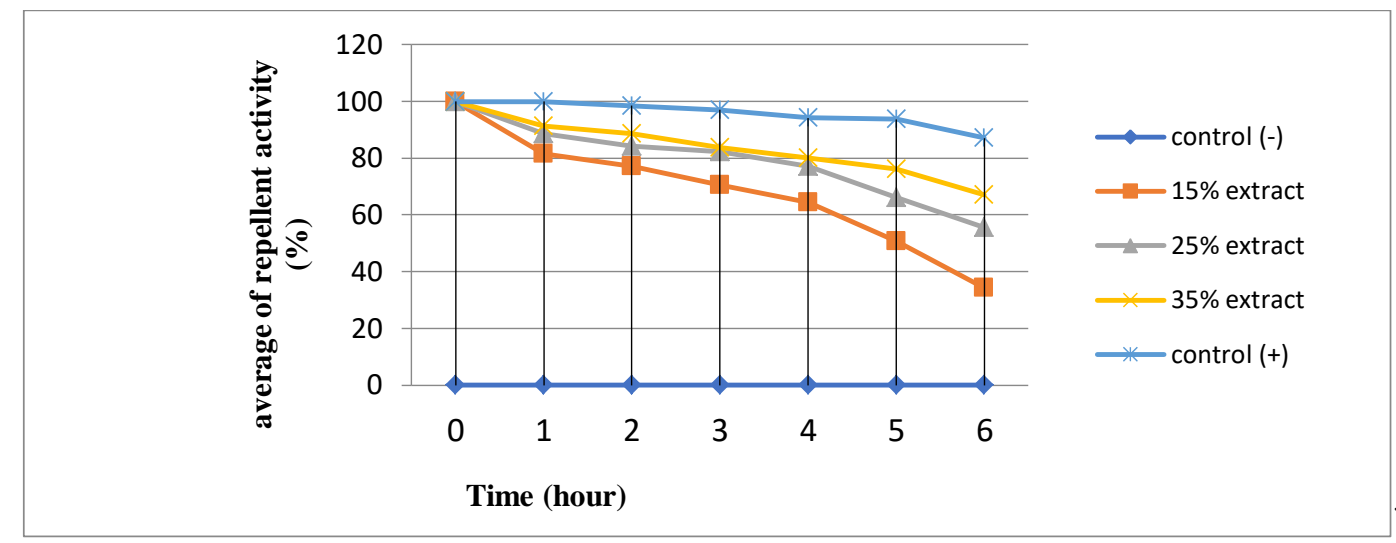

Graph 1 . The average percentage of $n$-hexane extract repellent activity against Aedes aegypti.

The graph above showed the effect of concentration variation on each hour. It is clearly shown that repellent activity correlates positively with concentration. Repellent activity correlates negatively with time.

A repellent activity test was done to show the effect of time against $n$-hexane bioactivity. Repellent activity test was done because of essential oils from Ocimum basilicum was volatile; linalool, geraniol, and eugenol are the phenolic compounds that have bioactivity as mosquito repellents. The result of the test for each concentration is shown in Table 1.

Table 1. Repellent activity (\%) of $n$-hexane extract from (Ocimum Basilicum) against Aedes aegypti

\begin{tabular}{llcccc}
\hline \multirow{2}{*}{ No } & $\begin{array}{c}\text { Concentration } \\
(\%)\end{array}$ & \multicolumn{2}{c}{ Repellent activity (\%), each repetition } & Average repellent activity (\%), after $\mathbf{6}$ hours \\
\cline { 3 - 4 } & \multicolumn{1}{c}{$\mathbf{1}$} & $\mathbf{2}$ & $\mathbf{3}$ & \\
\hline 1 & Control (-) & 0 & 0 & 0 & 0 \\
2 & $15 \%$ & 67,88 & 69,78 & 67,32 & 68,33 \\
3 & $25 \%$, & 79,37 & 78,43 & 79,70 & 79.17 \\
4 & $35 \%$ & 84,86 & 83,35 & 83,32 & 83,84 \\
5 & Control (+) & 97,00 & 94,32 & 95,67 & 95,80 \\
\hline
\end{tabular}

Based on Table 1, $n$-hexane extract of Ocimum basilicum stem and leaves extract can provide repellent activity against Aedes aegypti after 6 hours. The 
highest repellent activity was shown by the $35 \%$ concentration; the lowest repellent activity was shown by the $15 \%$ concentration.

One-way ANOVA test results of this research were $<0.001$, showing a significant difference between each concentration. A post hoc test was conducted to analyze a significant difference between each test group. The post hoc test shows a significant difference $(p<0.05)$ between negative control and each test group. A significant difference between negative control and each test group means that $n$-hexane extract of Ocimum basilicum stem and leaves have repellent activity against Aedes aegypti. A significant difference between the concentration of $15 \%$ and $25 \%, 15 \%$ and $35 \%$, and $25 \%$ and $35 \%$ were also found.

The estimated concentration for $90 \%$ effectiveness concentration (EC90) was calculated using the Probit test (Table 2). The concentration of $45.1398 \%$ was estimated to be $90 \%$ effective (EC90) against Aedes aegypti.

Table 2. Concentration calculated using Probit analysis

\begin{tabular}{ccccc}
\hline $\begin{array}{c}\text { Repellent activity } \\
(\%)\end{array}$ & Concentration (\%) & Confidence & \multicolumn{2}{c}{ Confidence interval } \\
\cline { 3 - 5 } & 45,1398 & $95.0 \%$ & Lower value & Upper value \\
\hline 90 & & 33,6663 & 264,63 \\
\hline
\end{tabular}

\section{DISCUSSIONS}

The increased concentration of the extract was positively correlated with repellent effectiveness. The result agrees with the theory that the majority of plants contain insect-repelling oils, especially from hematophagous arthropods. Volatiles, such as essential oils, are usually effective for repellent immediately after application because of more repelling substances in the air. After a while, the repelling activity is decreasing because of the lower number of molecules released. ${ }^{13}$

The number of bioactive compounds released by Ocimum basilicum stem and leaves depends on the solvents used during extraction. This research used $n$-hexane for extraction because of the non-polarity of it. $N$-hexane was used to extract nonpolar substances, such as essential oils. ${ }^{9}$ Some studies showed that $n$-hexane as the solvent is better for essential oil extraction because of its nonpolarity. $^{7}$

Ocimum basilicum stem and leaves contain bioactive essential oils composed of linalool, geraniol, and the eugenol that showed bioactivity as mosquito repellents. ${ }^{8}$ Repelling activity of essential oils come from volatile properties of bioactive substances. Volatile substances, under contact with body heat, evaporates and detected by mosquitoes' chemical receptors on the antennae; the chemical signals were transmitted into the brain and mosquitoes reflexively avoid the offending chemical substances. ${ }^{14}$

Bioactive substances from essential oils, such as linalool, may increase the insects' sensory nervous system activity. These chemical compounds are known to have unpleasant smells for mosquitoes and known as an insect repelling secondary metabolic substances. ${ }^{15}$ Linalool is actively avoided by the insects. ${ }^{4}$ Eugenol from essential oils from Ocimum basilicum stem and leaves have a strong odor that is avoided by mosquitoes. The odors are detected by chemical receptors on mosquitoes and mosquitoes will avoid the odor sources. ${ }^{16,17}$ Ocimum basilicum leaves also contain geraniol. Geraniol is highly avoided by insects, including mosquitoes, because of strong odor, therefore it might be utilized as insect repellent. ${ }^{18}$

Essential oils from Ocimum basilicum stem and leaves extract may create strong, unpleasant odors for 
mosquitoes. After being sprayed to hands or clothes, bioactive compounds from the essential oils will evaporate and creates unpleasant odors for mosquitoes. The odor molecules will bind with the chemoreceptors on mosquitoes' antennae. The antenna contains odorant-binding proteins (OBPs) that will bring the odor sensation into olfactory receptor neurons (ORNs). The receptor will translate the chemical signal into impulses that will be transmitted into the mosquitoes' central nervous system to create rejection responses or block the olfactory organs of the mosquitoes, therefore creating avoidant behavior. $^{14,19,20}$ The compounds on essential oils from Ocimum basilicum extracts works by blocking mosquitoes' olfactory organs and stopping the mosquitoes to recognize the prey.

Repellent activity of Ocimum basilicum extracts was compared with the synthetic repellant against Aedes aegypti for 6 hours test. Synthetic repellent used in this study contains 13\% DEET (n,ndiethyl-toluamide). The Ocimum basilicum extracts repelling activity was almost as high the synthetic with $83,84 \%$ to $95.80 \%$, respectively.

Combination of essential oils, containing linalool, geraniol, and eugenol, making Ocimum basilicum stem and leaves a potential candidate to be utilized as a natural repellent against Aedes aegypti. Natural repellent is thought to be able to reduce the toxic effect of synthetic repellent. Natural repellent is thought to create less toxic residue because of its hitand-run nature: after the repellent works, it will degrade quickly, so it is safer for the environment, pets, and humans. ${ }^{21}$ Natural repellent bioactive compounds are volatile, with pleasant smell to human after being sprayed to body. ${ }^{14,17}$

Ocimum basilicum stem and leaves extract are safer compared to synthetic repellents. Synthetic repellents usually contain DEET, a toxic compound with many side effects, such as skin irritation, insomnia, muscle cramps, and systemic toxicity; although DEET has proven its efficacy. ${ }^{5}$ Natural repellents, such essential oils, are safer because of lower residues compared to DEET and hoped to have lower long-term effects. ${ }^{21,22}$

\section{CONCLUSIONS}

This research showed that $n$-hexane extract from Ocimum basilicum stem and leaves showed repellent activity against Aedes aegypti with predicted EC90 of $45.13 \%$.

\section{REFERENCES}

1. Kemenkes RI. Profil Kesehatan Indonesia tahun 2015. Jakarta; Kemenkes RI: 2016.

2. Direktorat Jendral Pengendalian Penyakit dan Penyehatan Lingkungan. Modul Pengendalian Demam Berdarah Dengue. Jakarta; Kementerian Kesehatan Republik Indonesia: 2011.

3. Dinas Kesehatan Provinsi Sumatera Selatan. Profil Kesehatan Provinsi Sumatera Selatan Tahun 2014. Palembang; Dinas Kesehatan Provinsi Sumatera Selatan: 2015.

4. Kardinan, A. Tanaman Pengusir Nyamuk. Agromedia Pustaka. Jakarta: 2003.

5. Sentra Informasi Keracunan Nasional. Bahaya DEET Pada Insect-Repellent. Badan POM; 2016.

6. Putri, HL., Retnowati, R., Suratmo. Fraksi n-heksana Dari Ekstrak Metanol Daun Mangga Kasturi (Mangifera casturi Koesterm) Dan Uji Fitokimia. Kimia Student Journal. 2015;1(1):772777.

7. Winterianus, C., Gomarjoyo, H., Khomeini, A., Rahman, D., Sanjaya, AS. Pengaruh Jenis Pelarut Terhadap Rendeman Minyak Sereh Wangi. Teknik Kimia Fakultas Teknik 
Universitas

Mulawarman. 2015;14(2):57-61.

8. Aini, R., Widiastuti, R., Afra, N. Uji Efektifitas Formula Spray Dari Minyak Atsiri Herba Kemangi (Ocimum Sanctum L ) Sebagai Repellent Nyamuk Aedes aegypti. Jurnal Ilmiah Manuntung. 2016;2(2):189-197.

9. Dadang dan Prijono, D. Insektisida Nabati: Prinsip, Pemanfaatan, dan Pengembangan. Departemen Proteksi Tanaman Bogor. Fakultas Pertanian. IPB. 2008:163.

10. Direktorat Pupuk dan Pestisida. Metode Standar Pengujian Efikasi Pestisida Rumah Tangga dan Pengedalian Vektor. Direktorat Jendral Prasarana dan Sarana Pertanian Kementrian Pertanian; 2012.

11. United States Enviromental Protection Agency (USEPA). USEPA Product Performance Test Guidelines OPPTS 810.3700: Insect Repellents to be Applied to Human Skin. 2010.

12. Prabawati, Ari. Panduan Aplikatif dan Solusi Mengolah Data Statistik Hasil Penelitian dengan SPSS 17. Yogyakarta: Andi, Semarang: Wahana Komputer; 2010.

13. Kalita, B., Bora, S., Sharma AK. Plant Essential Oils As Mosquito Repellenta Review. Int. J. Res. Dev. Pharm. L. Sci. 2013;3(1):741-747

14. Ratnasari., NMD. Perbedaan Efektifitas Minyak Atsiri Bunga Kenanga (Cananga odorata) Sebagai Repelan Terhadap Gigitan NyamukAedes Aegypti Dengan Konsentrasi 5\%, 15\% Dan 25\%. Coping; Community of Publishing in Nursing. 2014: 2(3).

15. Marina, R., Astuti EP. Potensi Daun Pandan (Pandanus amaryllifolius) dan Dan Mangkokan (Notophanax Scutellarium) Sebagai Repellen Nyamuk Aedes albopictus. Aspirator. 2012; 4(2): 85-91.
16. Kristiyana, R. Optimasi Penambahan Ekstrak Etanol Daun Kemangi Sebagai Pengganti Triclosan Dalam Menghambat Staphylococcus aureusdan Eschericia coli Pada Produk Sabun Cuci Tangan Cair. Skripsi, Universitas Pakuan Bogor: 2013.

17. Magdalena, R., Miranti, U., Junjun, F. Uji Efektivitas Repellent Minyak Atsiri Daun Serai Wangi Cymbopogon nardus (L) Randle Yang Dikombinasi Dengan Minyak Atsiri Daun Kayu Putih (Melaleuca leucadendron Linn.) Dan Vco (Virgin Coconut Oil) Terhadap Nyamuk Aedes aegypti. Medika Tadulako, Jurnal Ilmiah Kedokteran, 2019; 6(1): 46-59.

18. Sanjaya, Y., Adi senjaya, Yusuf, H. dan Wijayanti, L. Efektivitas daya tolak ekstrak Geranium radula Cavan terhadap nyamuk Aedes aegypti (Linn.). Bionatura Jurnal Ilmu-ilmu Hayati dan Fisik. 2014; 16(2): 62-67.

19. Rachmah, Septya, Lailly., Ocky Dwi Suprobowati, Suliati. Efektivitas Mat Bunga Kenanga (Cananga Odorata) Sebagai Anti Nyamuk Elektrik Terhadap Nyamuk Aedes Aegypti. Jurnal Analis Kesehatan Sains, 2017;6(2): 501-507.

20. Saleh, M, Susilawaty A, Syarfaini S, Musdalifah M. Uji Efektivitas Ekstrak Kulit Buah Jeruk Nipis (Citrus aurantifolia) Sebagai Insektisida Hayati Terhadap Nyamuk Aedes aegypti. Jurnal Higiene. 2017;3(1):3036.

21. Wahid, Abdul. Efikasi Bioinsektisida Dan Kombinasinya Terhadap Serangan Hama Ulat Kantong Pagodiella spp. J. Agroland, 2010; 17(2):162-168

Setiyaningsih, R., Widiarti, W., Lasmiati L. Efikasi Larvasida Temephos Terhadap Aedes Aegypti Resisten Pada Berbagai Kontainer. Vektora. 2015;7(1): 23 - 28. 
Vol 5 No 3 October 2020

FARMATERA

E-ISSN: 2528-410X 